\title{
Pengaruh Model Pembelajaran Bamboo Dancing Terhadap Keterampilan Berpikir Kritis Pada Pembelajaran IPA
}

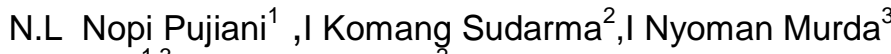 \\ 1,3 Jurusan PGSD, 2 Jurusan TP, FIP \\ Universitas Pendidikan Ganesha \\ e-mail: pujianinopi@gmail.com ${ }^{1}$,sudarmadede@gmail.com ${ }^{2}$, \\ murdanyoman@yahoo.co.id ${ }^{3}$
}

\begin{abstract}
Abstrak
Permasalahan rendahnya keterampilan berpikir kritis IPA siswa kelas V di Gugus V Kecamatan Kintamani menjadi masalah utama dilakukannya penelitian ini. Rendahnya keterampilan berpikir kritis karena pembelajaran yang masih berpusat pada guru sehingga siswa kurang mampu menemukan pengetahunnya sendiri. Oleh karena itu, penelitian ini dilakuakn dengan tujuan untuk mengetahui pengaruh keterampilan berpikir kritis IPA antara kelompok siswa yang dibelajarkan dengan model pembelajaran Bamboo Dancing dan kelompok siswa yang dibelajarkan dengan pembelajaran konvensional pada siswa kelas $\mathrm{V}$ di Gugus V Kintamani, Kecamatan Kintamani Tahun Pelajaran 2017/2018. Jenis penelitian ini adalah eksperimen semu, dengan desain Nonequivalen Post Test Only Control Group Desaign. Populasi dalam penelitian ini adalah seluruh kelas V SD di Gugus V Kintamani tahun pelajaran 2017/2018 yang berjumlah 176. Sampel penelitian yaitu kelas V SDN Daup sebagai kelompok eksperimen yang berjumlah 22 siswa dan kelas V SDN 1 Belantih sebagai kelas kontrol yang berjumlah 20 siswa, diperoleh dengan teknik random sampling melalui cara undian kelas. Metode yang digunakan dalam penelitian ini adalah metode tes. Data yang dikumpulkan dianalisis menggunakan statistik deskriptif dan statistik infrensial (uji-t). Hasil penelitian menunjukkan bahwa $t_{\text {hit }}=9,625$ dan $t_{\text {tab }}=$ (pada taraf signifikan 5\%) 2,021. Hal ini berarti $T_{\text {hitung }}>$ $\mathrm{T}_{\text {tabel }}$, sehingga terdapat pengaruh keterampilan berpikir kritis antara siswa yang belajar dengan model pembelajaran Bamboo Dancing dengan siswa yang dibelajarankan dengan pembelajaran konvensional. Berdasarkan hal tersebut, dapat disimpulkan bahwa model pembelajaran Bamboo Dancing berpengaruh terhadap keterampilan berpikir kritis IPA siswa.
\end{abstract}

Kata Kunci : Bamboo Dancing, Berpikir Kritis, IPA.

\begin{abstract}
The problem of this research is the lack critical thinking ability of $V$ grade in gugus $V$ Kintamani nature scicence students in Kintamani. This lack of critical thinking ability is caused by teacher-centered learning activity which does not support student to find the knowledge themselves. Therefore,this research is purposed to know the effect of critical thinking skill in learning science between the group of students that learn with Bamboo Dancing learning model and the group of students wich is taught by conventional to five grade studend $V$ Kintamani, kecamatan Kintamani district in 2017/2018. The research is quasi experiment with nonequivalent posttest-Only control group desaign. The population of this research is the second semester student in five grade in Gugus $V$ Kintamani, kecamatan Kintamani in academic year 2017/2018 wich are 176 students. Amounts 22 studendt from five grade student in SDN Daup as experiment group and amounts 20 students five grade students of SDN 1 Belantih as control group. The data method used is the test method. The score data of the collected were analized using descriptive statistics and inferential statistics (uji-t). the result of this study showed that thit $=9,625$ and $t$ tab $=($ in $5 \%$ significance level) $=2,021$. It means that Bamboo Dancing learning model and the group of students that wich is taught by conventional. Based of the results of this study, it can be concluded Bamboo Dancing Learning effect to critical thinking skill IPA student.
\end{abstract}

Keywords: Bamboo Dancing, Critical thinking skill, IPA. 


\section{Pendahuluan}

Pendidikan merupakan suatu proses yang diperlukan untuk mendapatkan keseimbangan dan kesempurnaan dalam perkembangan individu maupun masyarakat. Penekanan pendidikan dibanding dengan pengajaran terletak pada pembentukan kesadaran dan kepribadian individu atau masyarakat di samping transfer ilmu dan keahlian. Dengan proses semacam ini suatu bangsa atau negara dapat mewariskan nilai-nilai keagamaan, kebudayaan, pemikiran dan keahlian kepada generasi berikutnya, sehingga mereka betul-betul siap menyongsong masa depan kehidupan bangsa dan negara yang lebih cerah.

Pendidikan juga merupakan sebuah aktifitas yang memiliki maksud atau tujuan tertentu yang diarahkan untuk mengembangkan potensi yang dimiliki manusia baik sebagai manusia ataupun sebagai masyarakat dengan sepenuhnya (Nurkholis, 2013)

Pasal 1 UU SISDIKNAS no. 20 tahun 2003 disebutkan bahwa Sistem Pendidikan Nasional adalah keseluruhan komponen pendidikan yang saling terkait secara terpadu untuk mencapai tujuan pendidikan nasional. Berangkat dari bunyi pasal ini dapat diketahui bahwa pendidikan adalah sistem yang merupakan suatu totalitas struktur yang terdiri dari komponen yang saling terkait dan secara bersama menuju kepada tercapainya tujuan (Soetarno, 2003: 2). Adapun komponen-komponen dalam pendidikan nasional antara lain adalah lingkungan, sarana-prasarana, sumberdaya, dan masyarakat. Komponen-komponen tersebut bekerja secara bersama-sama, saling terkait dan mendukung dalam mencapai tujuan pendidikan (Munirah, 2015).

Berpikir kritis adalah suatu keterampilan yang harus diajarkan kepada individu sejak dini melalui pengetahuan-pengetahuan ataupun disiplin keilmuan agar berhasil dalam kehidupannya di masa mendatang, baik itu sebagai akademisi, profesional, wirausahawan, Pegawai Negeri Sipil (PNS) dan pegawai di perusahaan. Fein (1981) menyebutkan bahwa berpikir kritis pada anak mulai berkembang pada tahun-tahun pra sekolah yaitu usia 5-7 tahun. $\mathrm{Hal}$ ini kemudian menjadi penentu kreativitas cara menyelesaikan permasalahan di masa remajanya (Calvery \& Vilson, 2010), serta bagaimana ide-ide berpikirnya berkembang hingga dewasa (RootBreinstein, 2004) (Sulaiman, 2018).

Sekolah dasar merupakan salah satu lembaga formal pendidikan dalam struktur jenjang pendidikan nasional mengemban misi yang sangat strategis. Misi tersebut berkaitan dengan pengembangan sumber daya manusia (SDM) yang berkualitas. Terkait dengan pengembangan sumber daya manusia (SDM) yang berkualitas, suasana belajar di sekolah dasar perlu direncanakan dengan menggunakan pembelajaran yang efektif. Proses pembelajaran dikatakan efektif apabila seluruh peserta didik terlibat secara aktif baik mental maupun fisik (Susanto, 2013). Pembelajaran yang demikian harus terjadi pada semua mata pelajaran yang diterapkan di sekolah, termasuk pembelajaran IPA.

IPA merupakan mata pelajaran yang wajib diberikan di sekolah dasar. Mata pelajaran ini memegang peranan yang sangat penting dalam kehidupan sehari-hari. Susanto (2013:167) menyatakan, "sains atau IPA adalah usaha manusia dalam memahami alam semesta melalui pengamatan yang tepat pada sasaran, serta menggunakan prosedur, dan dijelaskan dengan penalaran sehingga mendapatkan suatu kesimpulan". IPA melatih siswa berfikir logis, rasional, kritis, kreatif dan berpikir secara ilmiah (Samatowa, 2016). Berdasarkan hal tersebut maka hakikat IPA yaitu IPA sebagai proses, produk dan sikap ilmiah. IPA sebagai proses merujuk pada keterampilan yang mengkaji fenomena alam dengan cara-cara tertentu, IPA sebagai produk merupakan kumpulan hasil kegiatan empirik dan kegiatan analitik, kemudian IPA sebagai sikap ilmiah merupakan sikap yang perlu dikembangkan dalam pembelajaran (Bundu, 2006).

Salah satu keterampilan yang harus dikembangkan dan dilatih sejak berada di sekolah dasar adalah keterampilan berpikir kritis (critical thinking). Keterampilan berfikir kritis sangat diperlukan karena keterampilan ini akan mendorong pada adanya refleksi tentang apa yang sudah dikerjakan, ide baru yang muncul dalam kegiatan tersebut, dan bagaimana kegiatan dapat dilakukan dengan lebih baik. Hasil refleksi ini akan menyadarkan siswa tentang kemungkinan adanya beberapa alternatif yang dapat dilakukan dalam satu kegiatan (Bundu, 2006). Selanjutnya, akan memunculkan berani berbeda pendapat karena hasil yang diperoleh akan dipandang sebagai kesimpulan yang sifatnya sementara (tentative) bergantung pada data dan fakta yang ada, sehingga berdampak pada pemahaman siswa dan hasil belajar. Apabila keterampilan berpikir kritis dilatih melalui pengalaman langsung dapat menyebabkan pemahaman siswa menjadi lebih luas dan hasil belajar yang diperoleh juga akan meningkat. 
Namun pada kenyaatannya, berpikir kritis siswa belum sesuai harapan, termasuk di sekolah dasar. Hal ini diketahui dari hasil wawancara, observasi, dan pencatatan dokumen terhadap guru kelas V SD di Gugus V Kecamatan Kintamani yang dilaksanakan pada tanggal 24 November 2017 hingga 29 November 2017. Hasil wawancara diperoleh keterangan dari sembilan guru mengatakan bahwa keterampilan berpikir kritis siswa sangat rendah dalam mengikuti pembelajaran. Hal ini dikarenakan 1) kurangnya pemahaman siswa dalam menerima materi pelajaran IPA, 2) kurangnya minat siswa dalam mengikuti pembelajaran, kemudian lima dari sembilan guru menyatakan kurang mengetahui bagaimana menciptakan pembelajaran yang menyenangkan, aktif dan kreatif sehingga guru tersebut menggunakan metode ceramah, diskusi, tanya jawab dan penugasan

Hasil wawancara diperkuat dengan hasil observasi, didapatkan hasil observasi yaitu pertama, dalam proses pembelajaran siswa terlihat kurang semangat mengikuti pembelajaran dan pada saat guru menerangkan, banyak siswa yang mengobrol dengan teman sebangkunya. Kedua, pada saat guru bertanya, hanya beberapa siswa yang menjawab yaitu siswa yang mendapat peringkat dan siswa lainnya diam serta takut dalam menjawab pertanyaan. Ketiga, siswa tidak dapat menjelaskan kembali tentang konsep yang telah dipelajari. Keempat guru hanya meminta siswa untuk mengerjakan pertanyaan-pertanyaan yang ada dibuku teks. Kelima, selama proses pembelajaran berlangsung guru kurang memberikan rumusan masalah, argumen, induksi dan memutuskan tentang materi yang diajarkan.

Selain observasi dan wawancara dilakukan pencatatan dokumen yang diperoleh dari guru mata pelajaran IPA kelas V SD di Gugus V Kecamatan Kintamani dengan KKM 66-75 disajikan pada tabel 1

Tabel 1. Hasil Tes Awal Keterampilan Berpikir Kritis Mata Pelajaran IPA Siswa Kelas V SD Di Gugus V Kecamatan Kintamani Semester I Tahun Pelajaran 2017/2018

\begin{tabular}{|c|c|c|c|c|c|c|c|c|}
\hline \multirow[t]{2}{*}{ No } & \multirow[t]{2}{*}{ Sekolah } & \multirow[t]{2}{*}{$\begin{array}{l}\text { Jumlah } \\
\text { siswa }\end{array}$} & \multirow[t]{2}{*}{$\begin{array}{l}\text { rata-rata } \\
\text { nilai }\end{array}$} & \multirow[t]{2}{*}{ KKM } & \multicolumn{2}{|c|}{$\begin{array}{l}\text { Siswa yang } \\
\text { sudah } \\
\text { mencapai } \\
\text { KKM }\end{array}$} & \multicolumn{2}{|c|}{$\begin{array}{l}\text { Siswa yang } \\
\text { belum } \\
\text { mencapai } \\
\text { KKM }\end{array}$} \\
\hline & & & & & Siswa & $\%$ & Siswa & $\%$ \\
\hline 1 & SDN 1 Belantih & 20 & 58,8 & 75 & 1 & 5 & 19 & 95 \\
\hline 2 & SDN 2 Belantih & 18 & 53,6 & 75 & 1 & 6 & 17 & 94 \\
\hline 3 & SDN 3 Belantih & 25 & 53,4 & 70 & 1 & 4 & 24 & 96 \\
\hline 4 & SD N Catur & 39 & 55,6 & 68 & 5 & 13 & 34 & 87 \\
\hline 5 & SDN Batukaang & 11 & 61,4 & 66 & 4 & 36 & 7 & 64 \\
\hline 6 & SDN Mengani & 10 & 52,5 & 70 & 1 & 10 & 9 & 90 \\
\hline 7 & SDN Belanga & 11 & 52,7 & 70 & 1 & 9 & 10 & 91 \\
\hline 8 & SDN Daup & 22 & 59,1 & 68 & 4 & 18 & 18 & 89 \\
\hline 9 & SDN Selulung & 20 & 53,8 & 70 & 3 & 15 & 17 & 85 \\
\hline \multicolumn{2}{|c|}{ Jumlah } & 176 & & & 21 & 12 & 155 & 88 \\
\hline
\end{tabular}

Berdasarkan Tabel 1 terlihat bahwa nilai rata-rata keterampilan berpikir kritis siswa masih rendah belum mencapai maksimal sesuai dengan KKM yang diterapkan oleh sekolah. Rata-rata nilai tes awal memperlihatkan bahwa keterampilan berpikir kritis siswa kelas $\mathrm{V}$ berada dalam kategori rendah.

Hasil wawancara, observasi dan pencatatan dokumen didukung oleh penelitian yang dilakukan Dianawati (2017). Dari hasil wawancara dan observasi yang dilakukan oleh Dianawati (2017) di SD No. 1 Ungasan Kecamatan Kuta Selatan di temukan bahwa, 1) pemahaman siswa dalam menerima materi pelajaran IPA masih sangat kurang, 2) kurangya aktifitas fisik dan berpikir kritis siswa dalam belajar, 3) kurangnya minat siswa dalam mengikuti pembelajaran, 4) kurang inovatifnya guru dalam mengemas pembelajaran, 5) proses pembelajaran berpusat pada guru, 6) guru hanya menggunakan metode ceramah, diskusi dan penugasan. Terlalu seringnya diterapkan metode tersebut menyebabkan siswa menjadi bosan dalam mengikuti pembelajaran serta siswa hanya sebagai penerima informasi yang disampaikan oleh guru tanpa menggali pengetahuannya sendiri, 7) pencatatan dokumen dari jumlah jumlah siswa kelas VA 35 orang diperoleh rata-rata skor sebesar 4,4 sedangkan dari jumlah siswa kelas VB 36 orang diperoleh rata-rata skor sebesar 4,0 dengan KKM 75.

Oleh karena masalah rendahnya berpikir kritis siswa pada mata pelajaran IPA beserta penyebabnya tersebut, perlu dicarikan solusi. Salah satu solusi yang digunakan adalah 
pembelajaran yang lebih inovatif dan menciptkan suasana belajar yang aktif dan efektif. Sejalan dengan hal tersebut, pembelajaran inovatif diharapkan dapat menarik minat siswa untuk mempelajari IPA yang berdampak pada peningkatan keterampilan berpikir kritis yang dicapai oleh siswa.

Berdasarkan hal tersebut maka dilakukan penelitian dengan menerapkan model pembelajaran yang dapat melibatkan siswa secara aktif di dalam proses pembelajaran dan dapat melatih berfikir siswa. Salah satu model yang dapat membantu mengembangkan keterampilan berpikir kritis siswa adalah model Bamboo Dancing. Keunggulan model Bamboo Dancing yaitu strukturnya yang jelas dan memungkinkan siswa untuk saling berbagi informasi dengan teratur Huda (2014). Dalam pembelajaran model Bamboo Dancing dapat melatih berfikir siswa, hal ini dikarenakan model pembelajaran Bamboo Dancing sangat cocok untuk pertukaran pengalaman, pikiran, dan informasi antar siswa sehingga pesan tersampaikan kepada siswa secara optimal. Yuniari (2017) menyatakan bahwa, memberikan kesempatan kepada siswa untuk berbagi informasi sehingga dapat membangun konsep (pemahaman) pada saat yang bersamaan dengan pasangan yang berbeda secara teratur. Model pembelajaran Bamboo Dancing adalah pembelajaran yang diawali dengan pengenalan topik oleh guru kepada siswa, kemudian siswa dapat bertukar informasi yang telah diperolehnya dengan siswa lain, sehingga dapat meningkatkan keterampilan berpikir kritis dalam mendiskusikan topik atau masalah dan menambah pengetahuan melalui konsep-konsep penting. Dengan demikian, keterampilan berpikir kritis siswa yang dibelajarkan dengan model Bamboo Dancing menjadi lebih baik. Berdasarkan pemikiran tersebut, maka dilakukan penelitian yang berjudul "Pengaruh Model Pembelajaran Bamboo Dancing Terhadap Keterampilan Berpikir Kritis Pada Pembelajaran IPA Siswa Kelas V di Gugus V Kecamatan Kintamani Tahun Pelajaran $2017 / 2018$

Tujuan penelitian ini adalah untuk mengetahui perbedaan keterampilan berpikir kritis pada mata pelajaran IPA antara kelompok siswa yang belajar dengan menggunakan model pembelajaran Bamboo Dancing dan kelompok siswa yang dibelajarkaan dengan pembelajaran konvensional pada siswa kelas SD di Gugus V Kecamatan Kintamani V Tahun Ajaran $2017 / 2018$.

\section{Metode}

Penelitian ini dilaksanakan di kelas V SD N Daup dan di kelas V SD N 1 Belantih di Gugus V Kintamani, Kecamatan Kintamani. Penelitian dilaksanakan pada rentang waktu semester genap Tahun Pelajaran 2017/2018 yang dilaksanakan pada tanggal 2 April 2018 hingga 30 April 2018.

Jenis penelitian ini adalah penelitian eksperimen semu (quasi experiment). Penelitian ini menggunakan desain Nonequivalent Posttest-Only Control Group Desain.Terdapat dua kelompok dalam penelitian ini yang dipilih secara acak. Kelompok pertama diberi perlakuan $(X)$ menggunkan model pembelajaran Bamboo Dancing dan kelompok yang lain tidak diberikan perlakuan (-) menggunakan model pembelajaran Bamboo Dancing. Kelompok yang diberika perlakuan disebut kelompok eksperimen dan kelompok yang tidak diberikan perlakuan disebut kelompok kontrol.

Pelaksanaan penelitian ini terdiri dari tiga tahap yakni tahap persiapan, tahap pelaksanaan, dan tahap pelaporan. Tahap persiapan terdiri dari merancang perangkat pembelajaran dan instrumen yang digunakan untuk penelitian, mengonsultasikan perangkat pembelajaran dan instrumen dengan pembimbing dan pakar, menguji instrumen yang digunakan untuk penelitian, melakukan analisis uji instrumen, merevisi instrumen penelitian yang telah dilakukan. Pada tahap pelaksanaan pertemuan diadakan sebanyak 8 kali pertemuan. 7 kali pertemuan untuk memberikan treatment dan 1 kali pertemuan untuk pemberian posttest. Langkah-langkah yang dilakukan pada tahap ini adalah memberikan perlakuan model Bamboo Dancing pada kelas eksperimen dan pembelajaran konvensional pada kelas kontrol, kemudian mengadakan posttest pada kelas eksperimen dan kelas kontrol. Pada tahap pelaporan yang dilakukan adalah melakukan analisis data dilanjutkan dengan pengujian hipotesis sesuai data yang diperoleh dan menyusun laporan penelitian sesuai dengan analisis data yang didapatkan.

Populasi dalam penelitian ini adalah keseluruhan siswa kelas V SD di Gugus V Kintamani, Kecamatan Kintamani tahun pelajaran 2017/2018 yang berjumlah 176 orang. Sampel pada penelitian ini dipilih dengan teknik Random Sampling, melalui cara undian kelas. Sebelum pengundian, dilakukan uji kesetaraan. Analisis yang digunakan dalam uji kesetaraan 
yaitu analisis varians satu jalur (ANAVA A). Berdasarkan analisis uji kesetaraan keterampilan berpikir kritis, pada taraf signifikansi $5 \%$, diperoleh nilai $F_{\text {hitung }}$ sebesar 1,23 dan nilai $F_{\text {tabel }}$ sebesar 1,99., Artinya seluruh kelas $\vee$ di Gugus $\vee$ Kintamani memiliki kemampuan akademik yang setara, sehingga pemilihan sampel dari populasi dapat dilakukan dengan teknik random. Berdasarkan hasil uji kesetaraan, dipilih 2 kelas sebagai sampel penelitian dari 9 kelas dalam populasi. Berdasarkan pengundian yang dilakukan, kelas yang menjadi sampel dalam penelitian dapat dilihat pada Table 2.

Tabel 2. Sampel Penelitian

\begin{tabular}{|c|c|c|c|c|}
\hline No. & Sampel & Kelompok & Pendekatan/Model Pembelajaran & Jumlah Siswa \\
\hline 1 & $\begin{array}{l}\text { Kelas V SDN } \\
\text { Daup }\end{array}$ & Eksperimen & Pembelajaran Bamboo Dancing & 22 \\
\hline 2 & $\begin{array}{l}\text { Kelas V SDN } \\
1 \text { Belantih }\end{array}$ & Kontrol & $\begin{array}{l}\text { Pembelajaran bukan dengan } \\
\text { pembelajaran Bamboo Dancing }\end{array}$ & 20 \\
\hline \multicolumn{4}{|c|}{ Total Sampel } & 42 \\
\hline
\end{tabular}

Metode yang digunakan untuk mengumpulkan data keterampilan berpikir kritis IPA yaitu metode tes pilihan ganda. setelah diberlakukannya model pembelajaran Bamboo Dancing dan pembelajaran konvensional. Instrumen perlu diujicobakan terlebih dahulu untuk mengetahui kelayakan instrumen tersebut. Suatu instrumen dikatakan layak digunakan jika memenuhi syarat instrumen yang baik. Maka dari itu, perlu dilakukan uji validitas, uji realibilitas tes, uji tingkat kesukaran tes, dan uji daya beda tes. Uji validitas isi dilakukan dengan cara konsultasi kepada dua pakar (judges) terkait dengan soal untuk mengukur keterampilan berpikir kritis dengan hasil perhitungan 1,00 kategori sangat baik, kemudian tes diuji cobakan ke sekolah. Berdasarkan hasil dengan jumlah responden 70 siswa didapatkan 26 butir tes valid dari 30 butir tes yang diujicobakan. Selanjutnya dari hasil uji realibilitas diperoleh koefisien realibilitas sebesar 0,6173 kategori tinggi. Kemudian, berdasarkan hasil uji coba tingkat kesukaran butir tes keterampilan berpikir kritis diperoleh 4 soal tergolong mudah, 25 butir soal tergolong sedang, dan 1 butir tes tergolong sukar. Hasil perhitungan taraf kesukaran tes $(\mathrm{Pp})$ adalah 0,57 dengan kriteria sedang. Selanjutnya uji daya beda tes keterampilan berpikir kritis IPA diperoleh 5 butir soal terklarifikasi kurang baik, 21 butir soal terklarifikasi cukup baik, dan 4 butir soal terklarifikasi baik. Hasil perhitungan daya beda tes (Dp) adalah 0,25 dengan kriteria cukup baik.

Pada penelitian ini digunakan dua metode analisis yaitu analisis statistik deskriptif dan analisis statistik inferensial. Metode analisis yang digunakan untuk menguji hipotesis dalam penelitian ini adalah uji-t sampel inependent (tidak berkorelasi). Sebelum dilakukan uji hipotesis dengan metode statistik inferensial, terlebih dahulu dilakukan uji prasyarat analisis meliputi uji normalitas sebaran data dengan menggunakan uji Chi-Kuadrat dan uji homogenitas varians dengan menggunakan uji $\mathrm{F}$.

\section{Hasil dan Pembahasan}

Data keterampilan berpikir kritis IPA kelompok eksperimen diperoleh melalui post test terhadap 22 orang siswa. Hasil tes menunjukan bahwa skor tertinggi adalah 25 dan skor terendah adalah 16. Dari skor yang diperoleh dapat dideskripsikan, yaitu mean, median, modus varians dan standar deviasi. Data keterampilan berpikir kritis IPA kelompok eksperimen, dapat disajikan ke dalam bentuk kurva polygon seperti pada gambar 1. 


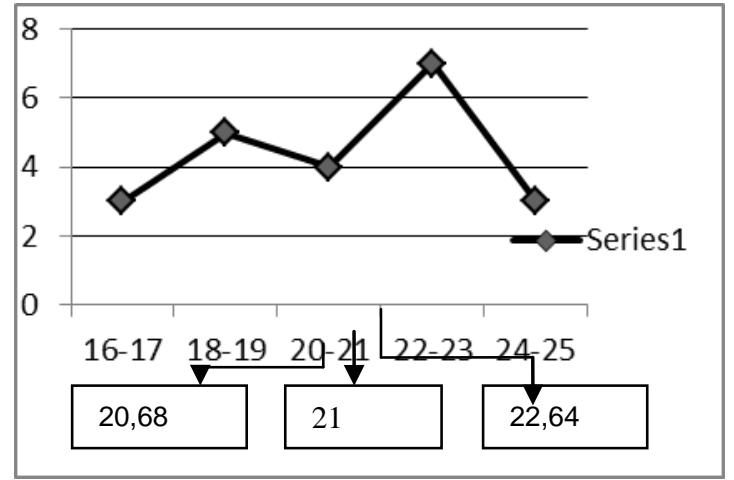

Gambar 1. Data keterampilan berpikir kritis IPA kelompok eksperimen

Berdasarkan kurva poligon di atas, dapat diketahui modus lebih besar dari median dan median lebih besar dari mean ( $M o>M d>M$ ), sehingga kurva yang tebentuk adalah kurva juling negatif. Artinya, skor yang diperoleh adalah cenderung tinggi.

Data keterampilan berpikir kritis IPA kelompok kontrol diperoleh melalui post test terhadap 20 orang siswa. Hasil observasi menunjukan bahwa skor tertinggi adalah 18 dan skor terendah adalah 9. Dari skor yang diperoleh dapat dideskripsikan, yaitu mean, median, modus, varians dan standar deviasi. Data keterampilan berpikir kritis IPA kelompok kontrol, dapat disajikan ke dalam bentuk kurva polygon seperti pada gambar 2 .

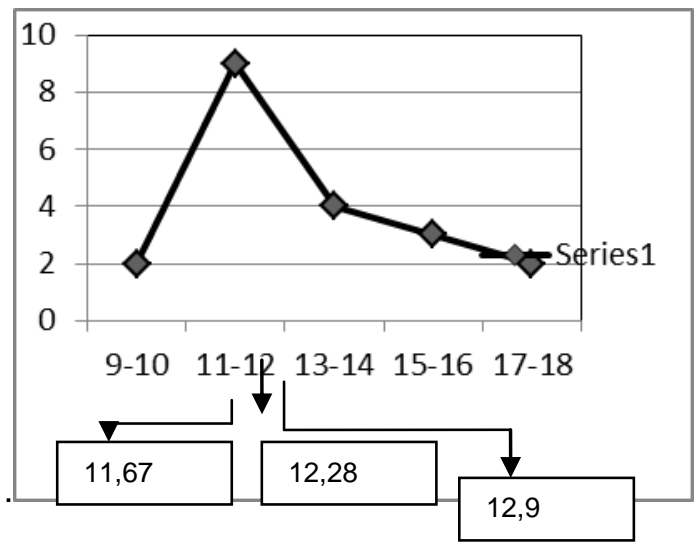

\section{Gambar 2.Kurva Poligon Data Keterampilan Berpikir Kritis IPA Kelompok Kontrol}

Berdasarkan kurva poligon di atas, dapat diketahui modus lebih kecil dari median dan median lebih kecil dari mean (Mo $<M d<M$ ), sehingga kurva yang terbentuk di atas adalah kurva juling positif. Artinya, skor yang diperoleh adalah cenderung rendah.

Selanjutnya sebelum melakukan uji hipotesis, dilakukan uji normalitas sebaran data dan homogenitas kelompok varians. Berdasarkan analisis data yang dilakukan, keterampilan berpikir kritis IPA berdistribusi normal dan homogen sehingga bisa dilanjutkan pada pengujian hipotesis menggunakan uji-t sampel independent (tidak berkolerasi) dengan rumus polled varians. Kriterianya Kriteria tolak $H_{0}$ jika $t_{h i t}>t_{t a b}$ dan terima $H_{0}$ jika $t_{h i t}<t_{t a b}$. Rangkuman hasil perhitungan uji-t keaktifan belajar dapat dilihat pada tabel 3 .

Tabel 3. Rangkuman Hasil Perhitungan Uji-t Keterampilan Berpikir Kritis IPA

\begin{tabular}{|c|c|c|c|c|c|c|c|}
\hline $\begin{array}{l}\text { Kelompok Data } \\
\text { keterampilan } \\
\text { berpikir kritis }\end{array}$ & $\begin{array}{l}\text { Mean } \\
(\bar{X})\end{array}$ & $S^{2}$ & $\mathrm{~N}$ & $\mathrm{Db}$ & $\mathrm{t}_{\text {hitung }}$ & $t_{\text {tabel }}$ & Kesimpulan \\
\hline Kelompok & 20,68 & 7,87 & 22 & 42 & 9,625 & 2,021 & $t_{\text {hitung }}>t_{\text {tabel }}$ \\
\hline
\end{tabular}


TSCJ, Vol 2 No 1, Tahun 2019

p-ISSN : 2615-4692 e-ISSN : 2615-6105

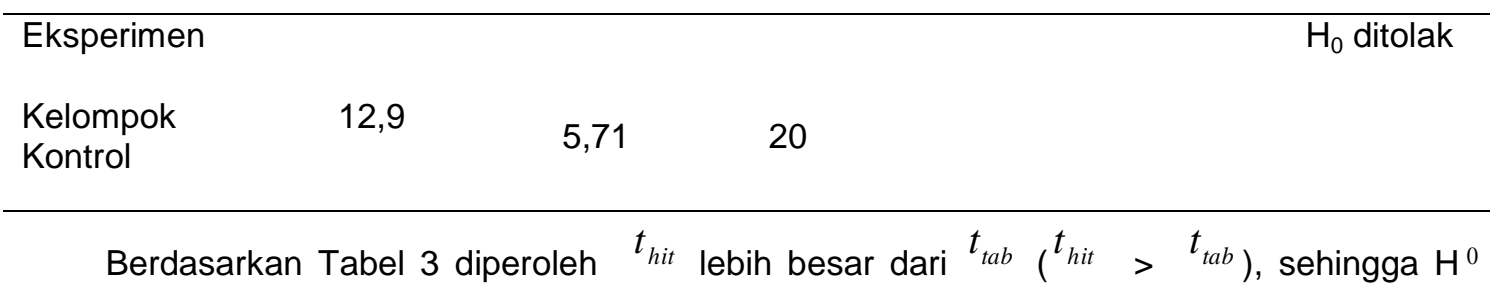

ditolak dan $\mathrm{H}^{1}$ diterima. Dengan demikian, terdapat perbedaan yang signifikan keterampilan berpikir kritis IPA antara kelompok siswa yang dibelajarkan dengan pembelajaran Bamboo Dancing dan kelompok siswa yang dibelajarkan dengan pembelajaran konvensional pada siswa kelas V SD di Gugus V Kintamani Kecamatan Kintamani Tahun Pelajaran 2017/2018.

Berdasarkan penelitian yang dilakukan, terdapat perbedaan rata-rata keterampilan ber[ikir kritis IPA pada kelompok eksperimen dan kelompok kontrol. Secara deksriptif keterampilan berpikir kritis IPA kelompok eksperimen lebih tinggi dibandingkan dengan kelompok kontrol. Perbedaan tersebut menunjukkan bahwa model pembelajaran Bamboo Dancing berpengaruh terhadap keterampilan berpikir kritis IPA siswa kelas V. Perbedaan keterampilan berpikir kritis tersebut disebabkan oleh beberapa faktor sebagai berikut.

Pertama, dalam pelaksanaan model pembelajaran Bamboo Dancing, dapat meningkatkan aktivitas pembelajaran yang menekankan pada proses pertukaran informasi sesuai topik. Siswa menemukan pengetahuannya sendiri melalui kerja kelompok dan pertukaran informasi. Ngalimun (2016) menyatakan bahwa model "tari bambu" memberikan kesempatan kepada siswa untuk berbagi informasi sehingga, dapat membangun konsep (pemahaman) pada saat yang bersamaan dengan pasangan yang berbeda secara teratur. Dengan pembelajaran secara berkelompok lebih memudahkan siswa dalam proses pembelajaran serta siswa dapat bertukar pikiran dengan anggota kelompoknya jika ada materi yang tidak dipahami.

Kedua, model pembelajaran Bamboo Dancing terdiri dari 4 sintaks pembelajaran yaitu (1) mengidentifikasi topik, (2) mengorganisasikan kelompok, (3) menyajikan informasi (bertukar informasi), dan (4) evaluasi. Dari keempat tahapan tersebut dapat meningkatkan keterampilan berpikir kritis.

Pada tahap pertama siswa diarahkan untuk mengidentifikasi topik. Sebagai contoh, pada saat pembelajaran berlangsung siswa sudah dituntut aktif menemukan informasi yang berkaitan dengan topik yang telah ditetentukan oleh guru. Kegiatan mengidentifikasi topik merupakan cara untuk memotivasi siswa untuk berpikir kritis sehingga dapat memunculkan rasa ingin tahu siswa dari hal yang diamati. Hal ini sejalan dengan penelitian Junaidi (2015:64-72) menyatakan bahwa "rasa ingin tahu mengawali terisinya berbagai pengetahuan dalam otak manusia". Rasa ingin tahu terjadi karena siswa menganggap bahwa sesuatu yang dipelajari merupakan hal yang baru yang harus diketahui untuk menjawab ketidaktahuannya.

Pada tahap kedua mengorganisasikan kelompok. Dalam pembelajaran model Bamboo Dancing guru mengarahkan siswa untuk membentuk dua kelompok besar yang berjajar, saling berhadapan dan bergeser searah jarum jam. Hal ini bertujuan untuk menciptakan suasana yang berbeda dari biasanya serta menarik minat siswa untuk mengikuti pembelajaran. Selain itu mengorganisasikan kelompok menciptakan kondisi dimana siswa bekerja sama dengan kelompoknya. Sejalan dengan penelitian Wahyuni (2017) yang menyatakan bahwa metode kerja kelompok pada pembelajaran ialah menciptakan peluang strategi pencapaian tujuantujuan pendidikan tertentu, terutama membangkitkan dan meningkatkan kemauan dan kemampuan bekerjasama di antara para siswa.

Pada tahap ketiga yaitu dalam menyajikan informasi/bertukar informasi. Dengan kemampuan berkomunikasi yang dimiliki, siswa dapat menyampaikan hasil pemikirannya terkait topik yang dibahas. Hal ini sejalan dengan pendapat Purwanti (2015) yang menyatakan bahwa kemampuan berkomunikasi terjadi dalam komunikasi dua arah yakni salah satunya melalui diskusi dan pembelajatran kelompok siswa dapat mengkomunikasikan pemikiran mereka pada teman-teman sekelas dan guru. Siswa yang biasanya diam pada proses pembelajaran dituntut untuk berkomunikasi secara aktif dalam berbagi informasi. Selanjutnya sejalan dengan pendapat Yogidibrata (2015) yang menyatakan kemampuan berkomunikasi dilakukan untuk bertukar gagasan pikiran, dan emosi. Siswa yang biasanya diam pada proses pembelajaran dituntut untuk berkomunikasi secara aktif dalam berbagi informasi.

Tahap keempat yaitu evalusi yang bertujuan untuk mengetahui kemampuan siswa dari apa yang telah dipelajari. Evaluasi merupakan upaya untuk memperoleh informasi tentang 
perolehan belajar siswa secara menyeluruh baik pengetahuan, sikap maupun keterampilan Bhakti (2017).

Ketiga, dalam melakukan sebuah penelitian tentunya ada hambatan yang ditemui selama penelitian berlangsung. Setelah diamati pada kelas eksperimen yaitu pada pertemuan pertama, kurangnya pemahaman guru terhadap model pembelajaran Bamboo Dancing sehingga pada proses pembelajaran berlangsung guru masih kebingungan dengan langkah-langkah kegiatan pembelajaran. Selain itu siswa juga kurang memahami langkah-langkah model pembelajaran dan siswa terlihat kebingungan dalam proses pembelajaran. Selain itu siswa juga kebanyakan bermain-main dalam proses pembelajaran berlangsung.

Hasil temuan pada penelitian ini memiliki persamaan dengan penelitian yang relevan dan memperkuat hasil penelitian yang diperoleh. Hal tersebut didukung dengan hasil penelitian yang pernah dilakukan Yuniari (2017) didapatkan bahwa terdapat pengaruh yang signifikan model pembelajaraan kooperatif tipe Tari Bambu (Bamboo Dancing) berbantuan lingkungan sekitar. Yuniari (2017) menjelaskan bahwa tingginya hasil belajar IPS disebabkan karena beberapa faktor yaitu siswa menemukan pengetahuan sendiri, meningkatnya motivasi belajar, meningkatkan aktivitas belajar. Penelitian lain juga didukung oleh hasil penelitian Arum (2016) hasil penelitian menunjukan model pembelajaran Bamboo Dancing dapat meningkatkkan minat belajar IPA. Analisis data yang diperoleh dari aktifitas belajar siswa yang telah sesuai dengan indikator siswa yang memiliki minat belajar baik, hal ini disebabkan karena beberapa tahapan yaitu pengenalan topik, membagi kelas menjadi 2 kelompok, berdiskusi dengan pasangan awal.

Selanjutnya hasil penelitian Yogidibrata (2015) menyatakan bahwa model pembelajaran Bamboo Dancing dapat meningkatkan perkembangan bahasa lisan anak. Hal ini dikarenakan diterapkannya model pembelajaran Bamboo Dancing sehingga terjadi peningkatan perkembangan bahasa lisan secara efektif. Hasil penelitian Huda (2015) didapatkan bahwa penerapan model pembelajaran Bamboo Dancing dapat meningkatkan pemahaman konsep perjuangan konsep perjuangan masa penjajahan jepang di Indonesia. Hal ini dapat dilihat dari peningkat nilai-nilai konsep pada setiap siklusnya selain itu adanya struktur model yang jelas sehingga memungkinkan siswa untuk berbagi informasi dalam pembelajaran. Penelitian Rifah (2017) menyatakan bahwa penerapan model pembelajaran Bamboo Dancing dapat meningkatkan pembelajaran IPS tentang perjuangan para tokoh menuju kemerdekaan siswa karena dilaksanakan dengan langkah-langkah: pengenalan topik/materi, pembagian kelompok besar, penempatan kelompok, pembagian tugas/LKS, pergantian pasangan, presentasi kelompok besar, dan refleksi. Kemudian penelitian dari Dewi (2016) menyatakan bahwa model pembelajaran Bamboo Dancing dapat meningkatan hasil belajar IPS siswa kelas $\mathrm{V}$ hal ini dikarenakan indikator yang sudah terpenuhi dalam pembelajaran dan pada siklus II terjadi peningkatan hasil belajar IPS dari siklus I. Kelemahan-kelemahan yang ada pada siklus I, telah dicari solusinya dan diterapkan pada siklus II.

Berdasarkan uraian yang telah dipaparkan, terlihat jelas bahwa model pembelajaran Bamboo Dancing dapat meningkatkan siswa aktif dalam proses pembelajaran. Dengan demikian dapat disimpulkan bahwa model pembelajaran Bamboo Dancing berpengaruh terhadap keterampilan berpikir kritis IPA siswa kelas V di Gugus V Kecamatan Kintamani Tahun Pelajaran 2017/2018

\section{Simpulan dan Saran}

Terdapat perbedaan yang signifikan keterampilan berpikir kritis antara kelompok siswa yang dibelajarkan dengan model pembelajaran Bamboo Dancing dan kelompok siswa yang dibelajarkan dengan pembelajaran konvensional pada siswa kelas V SD di Gugus V Kecamatan Kintamani Tahun Pelajaran 2017/2018. Hasil pengujian menunjukkan bahwa $t_{\text {hitung }}$ $(9,625)$ lebih besar daripada $t_{\text {tabel }}(2,021)$ pada taraf signifikansi $5 \%$ dengan $\mathrm{db}=40$. Model pembelajaran Bamboo Dancing berkontribusi dalam meningkatkan keterampilan berpikir kritis IPA siswa yaitu perubahan paradigma pembelajaran yang tadinya berpusat pada guru (theacer centered) menjadi berpusat pada siswa (student centered), hal tersebut dapat membuat siswa terlibat secara aktif dalam membangun pengetahuannya.

Saran yang dapat disampaikan berdasarkan penelitian yang telah dilakukan adalah sebagai berikut. (1) guru di sekolah dasar hendaknya menggunakan lebih banyak pembelajaran yang inovatif agar pembelajaran menjadi lebih bervariasi, salah satunya adalah model pembelajaran Bamboo Dancing. (2) kepala sekolah hendaknya mengikutkan guru-guru dalam pelatihan mengenai pembelajaran inovatif dan mengupayakan untuk menambah media pembelajaran yang relevan dengan pembelajaran di sekolah. (3) bagi peneliti lain, agar dilakukan penelitian kembali pengenai pengaruh model pembelajaran Bamboo Dancing 
terhadap keterampilan berpikir kritis IPA siswa. Selain itu, dapat dilakukan penelitian pembelajaran Bamboo Dancing dengan mencari variabel terikat lainnya di tempat penelitian berbeda, karena kajian penelitian yang dihasilkan akan dapat memberikan gambaran yang lebih jelas lagi mengenai keefektifan pembelajaran Bamboo Dancing terhadap keterampilan berpikir kritis.

\section{Daftar Pustaka}

Bhakti, Yoga budi. 2017. "Evaluasi Program CIPP Pada Proses Pembelajaran IPA". JIPFRI, Vol. 1 No. 2.

Bundu, Patta. 2006. Penilaian Keterampilan Proses dan Sikap IImiah dalam Pembelajaran Sains-SD. Jakarta: Departemen Pendidikan Nasional Direktorat Jendral Pendidikan Tinggi

Dewi Candra. 2016. "Implementasi Metode Bamboo Dancingl Untuk Meningkatan Hasil Belajar Ilmu Pengetahuan Sosial Pada Siswa Kelas V Sekolah Dasar". Jurnal Indria Vol 1,No 1 (2016)

Dianawati, Ni Luh Pt. 2017. " Pengaruh Model Pembelajaran Problem Based Learning Terhadap Keterampilan Berpikir Kritis Ipa Siswa Kelas V Sd No. 1 Ungasan Kecamatan Kuta Selatan Tahun Pelajaran 2016/2017 E-Journal Pgsd Universitas Pendidikan Ganesha Mimbar Pgsd Vol: 5 No: 2 Tahun: 2017.

Huda. Miftahul. 2015. "Penerapan Model Pembelajaran Kooperatif Tipe Bamboo Dancing Untuk Meningkatkan Pemahaman Konsep Perjuangan Pada Masa Penjajahan Jepang Di Indonesia". Jurnal Mahasiswa PGSD Vol 3, No 1 (2015

Junaidi, 2015. "Upaya Menumbuhkan Rasa Ingin Tahu Siswa Mengenaikonsep Matematika Menggunakan Abakus. Jurnal Pendidikan Dasar, 3 (1).

Ma'rifah. Nur. 2017. "Penggunaan Model Bamboo Dancing Dalam Peningkatan Pembelajaran IPS Siswa Kelas V Sekolah Dasar". Kalam Candekia Pgsd Kebumen Vol 6, No 6 (2017):

Munirah. 2015. Sistem Pendidikan Di Indonesia: Antara Keinginan Dan Realita . Jurnal Auladuna, Vol. 2 No. 2 Desember 2015: 233-245

Ngalimun. 2016. Strategi dan Model Pembelajaran. Yogyakarta: Aswanja Pressindo

Nurkholis. 2013. Pendidikan Dalam Upaya Memajukan Teknologi . Jurnal Kependidikan, Vol. 1 No. 1 Nopember 2013

Purwanti. 2015. "Meningkatkan Kemampuan Komunikasi dan Berpikir Kritis Matematis Siswa Sekolah Dasar Dengan Model Missouri Matematics Project (MMP) . Jurnal Pendidikan dan Keterampilan Dasar Volume 2 nomer 2

Samatowa, Usman. 2016. Pembelajaran IPA di Sekolah Dasar. Jakarta: PT Indeks.

Susanto, Ahmad. 2013. Teori Belajar dan Pembelajaran Di Sekolah Dasar. Jakarta: Prenadamedia Group.

Sulaiman, Ahmad. 2018. Berpikir Kritis: Mendorong Introduksi dan Reformulasi Konsep dalam Psikologi Islam .Jurnal UGM Buletin Psikologi ISSN 0854-7106 2018, Vol. 26, No. 2, 86 96 ISSN 2528-5858

Wahyuni, Sri. 2017. "Penerapan Metode Kerja Kelompok Untuk Meningkatkan Hasil Belajar IPS Pada Siswa Kelas III di SDN 15 Biau. Jurnal Kreatif Tadulako Online Vol. 5 No.

Yogidibrata. 2015. "Penerapan Model Pembelajaran Bamboo Dancing Berbantuan Media Gambar Untuk Meningkatkan Perkembangan Bahasa Lisan Anak Kelompok B3 Tk Widya 
TSCJ, Vol 2 No 1, Tahun 2019

p-ISSN : 2615-4692 e-ISSN : 2615-6105

Santhi Denpasara". E-Journal Pg-Paud Universitas Pendidikan Ganesha Jurusan Pendidikan Guru Pendidikan Anak Usia Dini (Volume 3 No 1 Tahun 2015).

Yuniari. Ni Wayan 2017. "Pengaruh Model Bamboo Dancing Berbantuan Lingkungan Sekitar Terhadap Hasil Belajar IPS Siswa Kelas V SD. E-Journal PGSD Universitas Pendidikan Ganesha Mimbar PGSD Vol: 5 No: 2 Tahun: 2017 